\title{
Papers
}

\section{The Ghost of Christmas Past: health effects of poverty in London in 1896 and 1991}

\author{
Danny Dorling, Richard Mitchell, Mary Shaw, Scott Orford, George Davey Smith
}

\begin{abstract}
Objectives To compare the extent to which late 20th century patterns of mortality in London are predicted by contemporary patterns of poverty and by late 19th century patterns of poverty. To test the hypothesis that the pattern of mortality from causes known to be related to deprivation in early life can be better predicted by the distribution of poverty in the late 19 th century than by that in the late 20th century. Design Data from Charles Booth's survey of inner London in 1896 were digitised and matched to contemporary local government wards. Ward level indices of relative poverty were derived from Booth's survey and the 1991 UK census of population. All deaths which took place within the surveyed area between 1991 and 1995 were identified and assigned to contemporary local government wards.

Standardised mortality ratios for various causes of death were calculated for each ward for all ages, under age 65 , and over age 65 . Simple correlation and partial correlation analysis were used to estimate the contribution of the indices of poverty from 1896 and 1991 in predicting ward level mortality ratios in the early 1990 s.

Setting Inner London.

Results For many causes of death in London, measures of deprivation made around 1896 and 1991 both contributed strongly to predicting the current spatial distribution. Contemporary mortality from diseases which are known to be related to deprivation in early life (stomach cancer, stroke, lung cancer) is predicted more strongly by the distribution of poverty in 1896 than that in 1991. In addition, all cause mortality among people aged over 65 was slightly more strongly related to the geography of poverty in the late 19th century than to its contemporary distribution.
\end{abstract}

Conclusions Contemporary patterns of some diseases have their roots in the past. The fundamental relation between spatial patterns of social deprivation and spatial patterns of mortality is so robust that a century of change in inner London has failed to disrupt it.

\section{Introduction}

"They [left the busy scene, and] went into an obscure part of the town, where Scrooge had never penetrated before, although he recognised its situation, and its bad repute. The ways were foul and narrow; the shops and houses wretched; the people half-naked, drunken, slipshod, ugly. Alleys and archways, like so many cesspools, disgorged their offences of smell, and dirt, and life, upon the straggling streets; and the whole quarter reeked with crime, with filth, and misery."

With these words Charles Dickens describes Scrooge's journey with the Spirit of Christmas Yet to Come into the poorest streets of London to view the body of Tiny Tim, the child his miserliness will kill if it continues unchecked. Dickens's A Christmas Carol also helped open the eyes of non-fictitious Londoners to the extent of poverty in their city at a time when social views were rapidly changing. Charles Booth was a contemporary chronicler of fact rather than fiction; together with his researchers he surveyed these same streets so that we can see today where the Tiny Tims of the past lived. Using Booth's map of poverty at the end of the 19th century we test the hypothesis of the Spirit of Christmas Yet to Come: that miserliness in the past and present leads to future inequalities in health.

Today, poverty at all stages of life is implicated in determining the risk of mortality, ${ }^{2}$ and relationships between the spatial distribution of poverty and mortality are well known and robust. ${ }^{3}$ It is also clear that there are specific relationships between adverse circumstances in childhood and the subsequent risk of particular causes of death in adulthood. ${ }^{4}$ We seek to illustrate here one example of where the spirits of Christmases past-even those before childhoodhave a strong influence on inequalities in health today.

Charles Booth's study of poverty in London was published between 1889 and 1903 in 17 volumes under the title of Life and Labour of the People of London. $^{5-19}$ Booth's survey covered over 120000 households, an area bounded by Pentonville prison to the north, Millwall docks to the east, Stockwell smallpox hospital to the south, and Kensington Palace to the west. The information that Booth and his 20 researchers collected was projected on to a series of detailed and exact maps, the most important of which was the Descriptive Map of London Poverty (see fig 1). ${ }^{20}$ This map shows the streets of London, building by building, coloured to correspond to a classification of the resident population of the time. Booth's seven category classification scheme is described in table 1 .

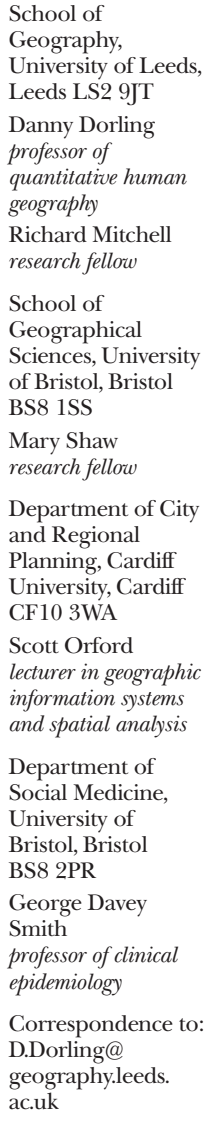

Correspondence to: D.Dorling@ geography.leeds. ac.uk

BMJ 2000;321:1547-51 


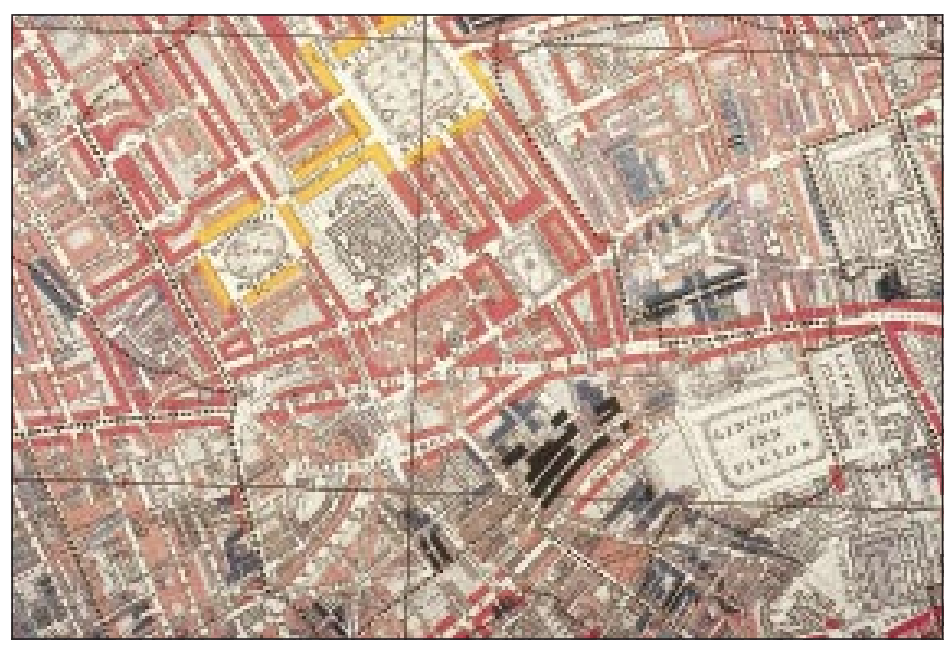

Fig 1 Detail of Booth's map of London poverty. ${ }^{20}$ Yellow indicates the highest social class, black the lowest class is related to its position within the class hierarchy. The extent of poverty within a class has thus been estimated using the number of people in higher social classes. The index for a particular ward is:

Ward Poverty Index $=$

$\left(\mathrm{I}{ }^{\mathrm{w} I}+\mathrm{II}{ }^{*} \mathrm{wII}+\mathrm{III}{ }^{*} \mathrm{wIII}+\mathrm{IV}{ }^{*} \mathrm{wIV}+\mathrm{V} *_{\mathrm{wV}}\right) /$

$(\mathrm{I}+\mathrm{II}+\mathrm{III}+\mathrm{IV}+\mathrm{V})$

where $\mathrm{I}$ is the number of households in class $\mathrm{I}$ in the ward at that time and wI is the socioeconomic position indicator associated with that class shown in table 1. This indicator relates to the proportion of the population that is at a higher socioeconomic level than the midpoint of the group. For 1991, 9.2\% of households are in social class I, so $4.6 \%$ of them are above the midpoint of this category and the indicator is $0.046 ; 37.3 \%$ of households are in social class II and it is assumed that all social class I households and half of social class II households are at a higher socioeconomic level than the midpoint of this group. Thus the indicator for social class II households is $0.092+0.186=0.278$. Similar logic is applied to calculation of the indicators for social classes III to V. The formulas to calculate indicators of socioeconomic position are given in the footnote to table 1 .

The index was low (approaching 0 ) in areas where large numbers of the resident households were in more affluent social classes and high in areas where they were in less affluent social classes. Similar logic was applied to calculation of the 1896 indicators. The use of such indicators takes into account the fact that the distributions of socioeconomic groups in 1896 and 1991 were different (such indicators have been widely used in inequalities in health research ${ }^{25-27}$ ). This index measures level of affluence for each ward in the study area and not inequality within them.

Figure 2 shows two images of Providence Place in Islington, north London, taken more than 100 years apart. Note how the number of people has fallen, as it has fallen in London as a whole over this period, and that the open drain has been covered. However, the social position of Providence Place in the geographical ranking of London streets remains much the same.

We compared the relative predictive power of the two poverty measures as they varied for specific causes of death and for different age groups. In particular, stroke and stomach cancer, as causes shown to be related to deprivation in early life, may be better predicted by a historical poverty measure. ${ }^{58}$ Age and sex standardised mortality ratios for each ward were

Table 1 Booth's classes (1896) and registrar general's classes (1991)

\begin{tabular}{|c|c|c|c|c|c|c|}
\hline $\begin{array}{l}\text { Colour on } \\
1896 \text { map }\end{array}$ & Booth's description & $\begin{array}{c}\% \text { of } \\
\text { households } \\
\text { in } 1896\end{array}$ & $\begin{array}{l}\text { Equivalent } \\
\text { registrar } \\
\text { general's class }\end{array}$ & $\begin{array}{l}\% \text { of households } \\
\text { in } 1991^{*}\end{array}$ & $\begin{array}{l}1896 \text { SEP } \\
\text { indicatorf }\end{array}$ & $\begin{array}{l}1991 \text { SEP } \\
\text { indicator† }\end{array}$ \\
\hline Black & Lowest class; vicious, semi-criminal & $1.5 \neq$ & & & & \\
\hline Blue & Very poor; casual labour, chronic want & $3.7 \ddagger$ & V§ & 6.9 & 0.937 & 0.965 \\
\hline Light blue & Poor; 18-21 shillings a week for a moderate family & $7.4 \ddagger$ & & & & \\
\hline Purple & Mixed; some comfortable, others poor & 16.2 & IV & 12.8 & 0.794 & 0.867 \\
\hline Pink & Fairly comfortable; good ordinary earnings & 35.2 & III & 33.8 & 0.537 & 0.634 \\
\hline$\overline{\text { Red }}$ & Well to do; middle class & 27.7 & II & 37.3 & 0.223 & 0.278 \\
\hline Yellow & Wealthy; upper middle and upper classes & 8.4 & I & 9.2 & 0.042 & 0.046 \\
\hline
\end{tabular}

*Excludes households with no social class allocation in the 1991 census (those described as in the army, inadequately described, and others without a social class). †Socioeconomic position indicators are cumulative proportions: for class I, (I/2)/(I+II+III+IV+V); for class II, (I+II/2)/(I+II+III+IV+V); for class III, (I+II+III/2)/ $(I+I+I I+I V+V)$; for class IV, $(I+I I+I I+I V / 2) /(I+I I+I I+I V+V)$; for class V, $(I+I I+I I+I V+V / 2) /(I+I++I I+I V+V)$. łPoor families made up $12.6 \%$ of households in 1896 .

$\S$ Includes people of working age who have not worked in the last 10 years. 

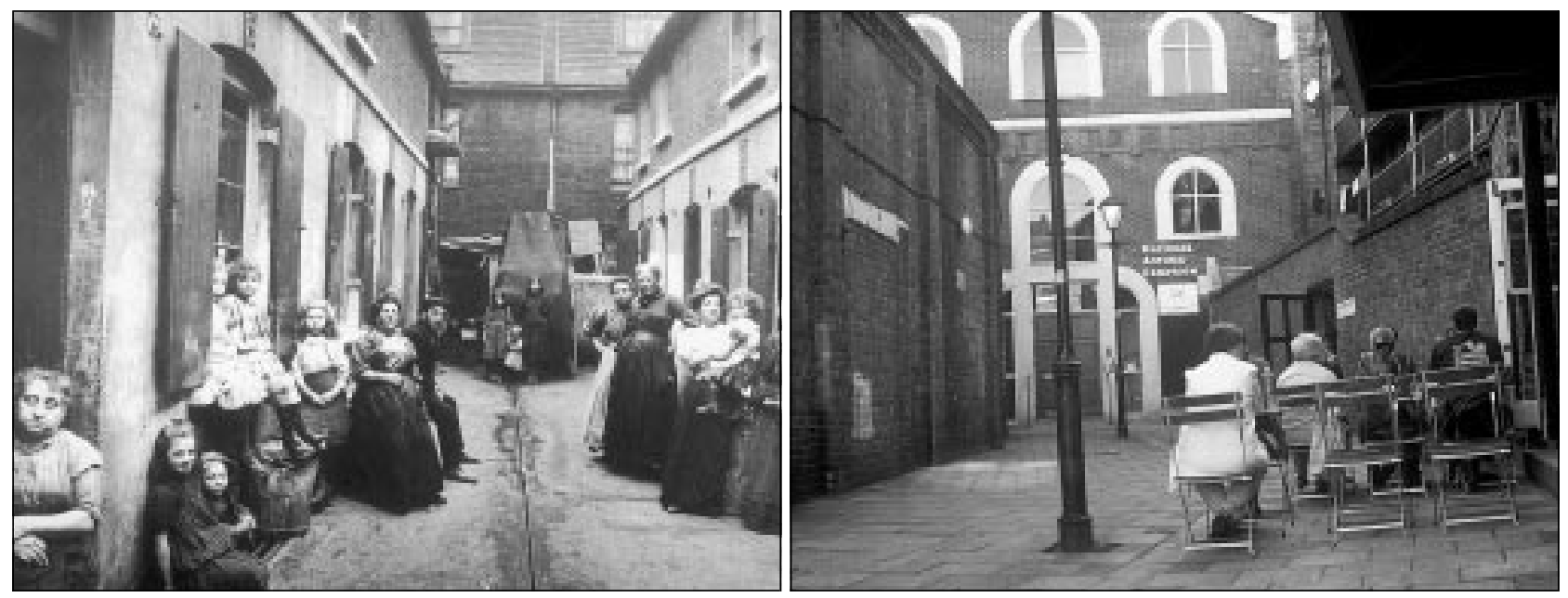

Fig 2 Providence Place, Islington, c1900 (left) and 2000 (right)

thus calculated for the causes of death shown in table 2 and for all deaths which took place between 1991 and 1995. The analysis comprised simple weighted and partial correlations in which ward mortality ratios were predicted by the two measures of poverty. The population of each ward provided the weights. Partial correlation analysis was also used to ascertain the extent to which predictive power was duplicated between the indices. All analyses were carried out in SPSS.

\section{Results}

Figure 3 shows three maps of the study area in inner London, allowing a comparison of the geography of poverty in the late 19th century (top) with that in the late 20th century (middle) and with mortality ratios for all causes for all ages (bottom). The correlation coefficient between the two measures is 0.73 $(\mathrm{P}<0.001)$. The blank area in the middle of the maps marks the City of London, which was not surveyed by Charles Booth. Figure 3 shows that there has been little change in the distribution of poverty in inner London between the 19th and 20th centuries. Areas in which some groups of immigrants settled in the middle of the 20th century have moved down the social scale slightly, notably south of the River Thames, while others have gentrified. On the whole, though, affluent places have remained affluent and poor places have remained relatively poor-two images of the Albert Bridge 100 years apart (fig 4) show part of the reason for this continuity - the perseverance of transport infrastructure. The map of all age ratios, showing all cause mortality, demonstrates the close relation between poverty and mortality.

Table 2 shows the simple and partial correlations between the poverty measures and the standardised mortality ratios for 1991-5. Both indices of poverty were related to all cause ratios. The partial correlation coefficients in the table also show that the index of poverty derived from Booth's 19th century observations (Booth index) contributed more to predicting deaths from stroke and stomach cancer in the late 20th century than that derived from the 1991 census (modern index). For other causes of death, the modern index contributed more.

The results of further correlation analyses suggest that for deaths under the age of 65 the modern index makes a slightly greater contribution to predicting all cause mortality in 1991-5 $(r=0.56, \mathrm{P}<0.001)$ than does the Booth index $(r=0.46, \mathrm{P}<0.001)$. This is substantiated by the results of the partial correlation analyses, where $r=0.39(\mathrm{P}=<0.001)$ when mortality is correlated with the Booth index, controlling for the modern index, but $r=0.08(\mathrm{P}=0.36)$ when mortality is correlated with the latter, controlling for the former.

When only deaths at ages greater than 65 are considered, however, both indices make a similar

Table 2 Strength of relation between poverty in 1896 (Booth index) and 1991 (modern index) and standardised mortality ratios for all ages for deaths in 1991-5

\begin{tabular}{|c|c|c|c|c|c|c|c|c|}
\hline & \multicolumn{2}{|c|}{$\begin{array}{l}\text { Correlation of Booth } \\
\text { index and mortality }\end{array}$} & \multicolumn{2}{|c|}{$\begin{array}{l}\text { Partial correlation of } \\
\text { Booth index and } \\
\text { mortality (controlling } \\
\text { for modern index) }\end{array}$} & \multicolumn{2}{|c|}{$\begin{array}{c}\text { Correlation of } \\
\text { modern index and } \\
\text { mortality }\end{array}$} & \multicolumn{2}{|c|}{$\begin{array}{l}\text { Partial correlation of } \\
\text { modern index and } \\
\text { mortality (controlling for } \\
\text { Booth index) }\end{array}$} \\
\hline & $r$ value & $P$ value & $r$ value & $P$ value & $r$ value & $P$ value & $r$ value & $P$ value \\
\hline All causes & 0.56 & $<0.001$ & 0.22 & 0.012 & 0.60 & $<0.001$ & 0.35 & $<0.001$ \\
\hline Coronary heart disease & 0.58 & $<0.001$ & 0.21 & 0.015 & 0.65 & $<0.001$ & 0.41 & $<0.001$ \\
\hline Stroke & 0.40 & $<0.001$ & 0.22 & 0.013 & 0.36 & $<0.001$ & 0.11 & 0.20 \\
\hline All cardiovascular disease & 0.56 & $<0.001$ & 0.20 & 0.023 & 0.61 & $<0.001$ & 0.37 & $<0.001$ \\
\hline Chronic obstructive pulmonary disease & 0.58 & $<0.001$ & 0.24 & 0.005 & 0.61 & $<0.001$ & 0.35 & $<0.001$ \\
\hline Pneumonia & 0.26 & 0.002 & 0.07 & 0.45 & 0.30 & $<0.001$ & 0.17 & 0.055 \\
\hline Lung cancer & 0.61 & $<0.001$ & 0.30 & 0.001 & 0.62 & $<0.001$ & 0.33 & $<0.001$ \\
\hline Stomach cancer & 0.49 & $<0.001$ & 0.24 & 0.007 & 0.47 & $<0.001$ & 0.20 & 0.020 \\
\hline Accidents and suicide & 0.05 & 0.56 & -0.14 & 0.10 & 0.21 & 0.012 & 0.24 & 0.005 \\
\hline
\end{tabular}




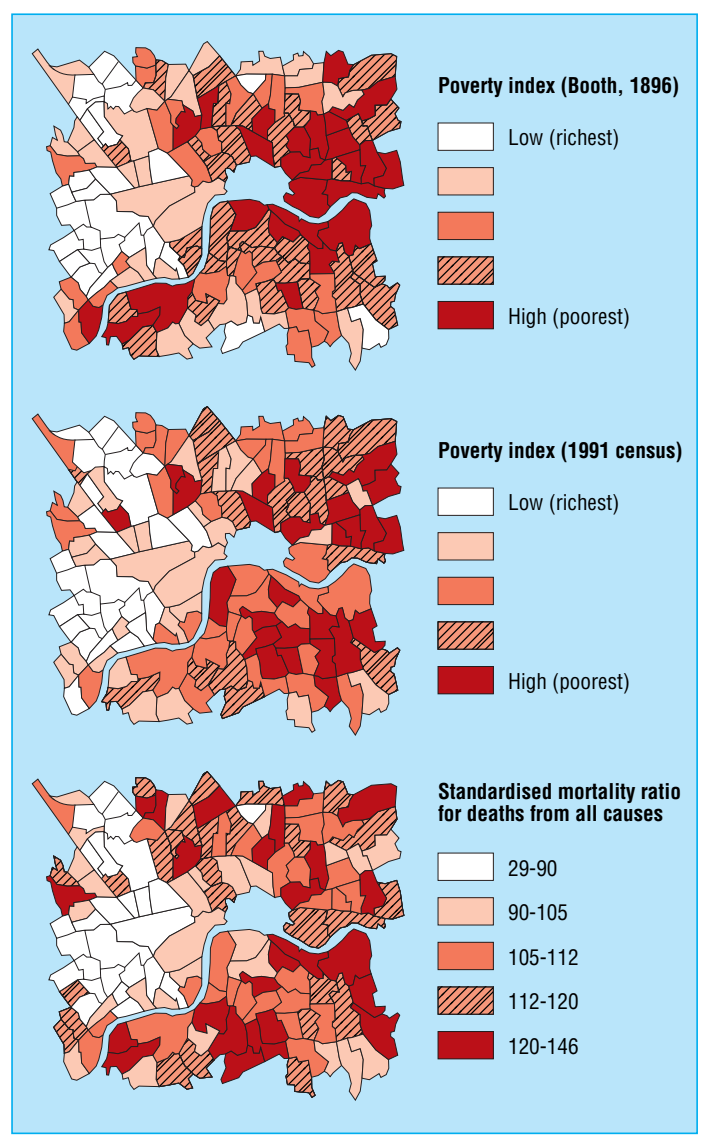

Fig 3 London poverty in 1896 (top) and 1991 (middle) and mortality in the 1990s (bottom)

contribution to the model; the correlation coefficients are $r=0.56(\mathrm{P}<0.001)$ and $r=0.57(\mathrm{P}<0.001)$ respectively. Here the results of the partial correlations also suggest a similar contribution from each index $(r=0.28, \mathrm{P}=0.001$ for the Booth index, controlling for the modern; $r=0.26, \mathrm{P}=0.002$ when the indices are reversed).

\section{Discussion}

Almost everyone who was surveyed by Booth at the end of the 19th century will have died or left London before 1991. This means that the 19th century poverty index is truly ecological-it describes "area type" rather than the aggregate characteristics of the resident population. The fact that it performs so strongly as a predictor of mortality is perhaps partly because the median age of death of the people dying in the period 1991-5 is approximately 78. This means that, while very few would have been alive at the time Booth surveyed London, approximately half of these people would have been born before 1915. The Booth index is thus an indicator of the early life circumstances of those dying in the period 1991-5. The majority of those people, however, will have migrated in the intervening period. Thus the predictive power of the Booth index is also an illustration of how the nature (and hierarchy) of different parts of London has remained relatively stable despite constant changeover of the resident individuals (illustrated by the similarities between the top and middle maps in fig 3). One might have expected to see considerable change in London's social and spatial structure given a century which included the Blitz in the second world war and the development of London into an ever more dynamic major world city, but it is perhaps the continuity over this period which is most remarkable. Even the big wheel built to celebrate the millennium is not new-one just three quarters of its size was built a century ago in London (see fig 5).

The social segregation of London is maintained through many processes. One that is particularly important is through the maintenance of differential housing values across the capital, which help steer patterns of migration within London. However, we have no way of knowing the migration histories of the individuals who died between 1991 and 1995. Thus these results will not reveal whether the high rates of mortality found in areas which have been continuously poor throughout are due to the continuous inward migration of a population at relatively higher risk of mortality (perhaps forced into cheaper accommodation, for example) or to some accumulative mortality risk raising the effects of day to day life in the area. The fact that the index of poverty derived from Booth's survey is related more strongly to causes of death that have previously been shown to be sensitive to deprivation in early life-that is, stroke and stomach cancer $^{5}{ }^{28}$ - suggests that to some degree the ecological associations with past and present deprivation levels of areas do reflect individual level associations of deprivation at different stages of the life course and health

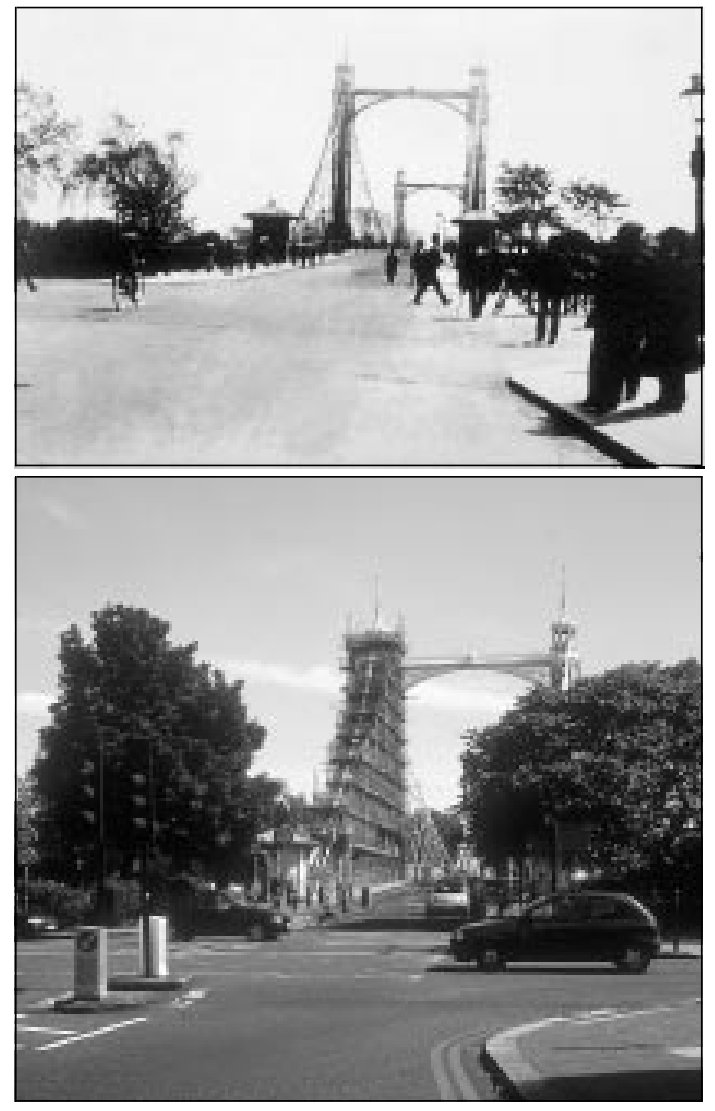

Fig 4 Albert Bridge, Chelsea c1900 (top) and 2000 (bottom). The main change is that the trees have grown: 100 years is long in the lifespan of humans but not in that of a city 
outcomes. In short, the longer people spend both in poverty and in poor places, the earlier they tend to die. The maps and models also show that 100 years of policy initiatives have had almost no impact on the patterns of inequality in inner London and on the relationship between people's socioeconomic position and their relative chances of dying.

We thus have a different ending to A Christmas Carol from that given by Dickens below. The hypothesis of the Spirit of Christmas Yet to Come seems to be true-inequalities in health have not declined, partly because miserliness in the past does lead to future inequalities in health. Dickens advocated redistribution of wealth at the end of his tale. Wilkinson has suggested that greater income equality is beneficial for the health of the whole populationincluding the relatively affluent-not just for those who are badly off..$^{29}$ In Dickens's story such redistribution not only aided the family of Tiny Tim, it also benefited Scrooge himself.

"A merrier Christmas, Bob, my good fellow, than I have given you for many a year! I'll raise your salary, and endeavour to assist your struggling family ... Scrooge was better than his word. He did it all, and infinitely more; and to Tiny Tim, who did NOT die, he was a second father ... His own heart laughed: and that was quite enough for him."'

We thank Kevin Holohan for digitising work, Nichola Tooke for historical research, and Jonathan Tooby for photographic advice.

Contributors: DD coordinated the study and calculated mortality rates and the indices of poverty. MS drafted the paper and was responsible for the literature review, historical work, and the photographs. SO undertook the geographical information systems analysis to transform the Booth map to current census geographies and helped edit the paper. RM and GDS undertook the statistical analysis. DD is the guarantor.

Funding: The study was supported by ESRC Health Variations Programme grants L128251009, L128251007, and

\section{What is already known on this topic}

People's health is strongly related to their material circumstances throughout their lives and particularly in childhood

Places in which people had poor health in the past tend still to contain people with relatively poor health today

\section{What this study adds}

At least in central London, a measure of the relative poverty and affluence of places made over 100 years ago is, for many causes of death, as useful a predictor of current inequalities in health as is the 1991 census

Together, the last census and the Booth index of 1896 better predict inequalities in health seen across London in the 1990s

The key message of A Christmas Carol-that redistribution of wealth reduces inequalities in mortality -is as relevant today as when it was written over 150 years ago; the fact that inequalities in health persist and match the 19th century pattern of inequalities in wealth so well suggests that that message has yet to be heeded
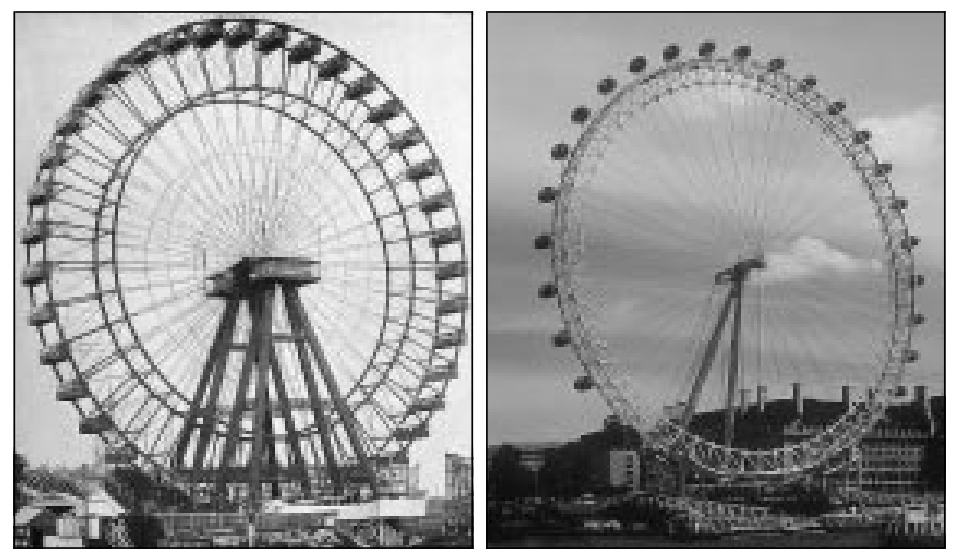

Fig 5 The big wheel at Earl's Court (1896, left) was three quarters the size of the London Eye (2000, right)

L128251037; ESRC fellowship R000271045; and Joseph Rowntree Foundation project Inequalities in Life and Death. Competing interests: None declared.

1 Dickens C. A Christmas carol.London: Chapman and Hall, 1843.

2 Davey Smith G, Hart C, Gillis C, Hawthorne V. Lifetime socioeconomic position and mortality: prospective observational study. BMJ 1997;314:547-52

3 Shaw M, Gordon D, Dorling D, Davey Smith G. The widening gap: health inequalities and policy in Britain. Bristol: Policy Press, 1999.

4 Davey Smith G, Hart C, Blane D, Hole D. Adverse socioeconomic conditions in childhood and cause specific adult mortality: prospective observational study. BMJ 1998;316:1631-5.

5 Aves E. Obituary: Charles Booth. Econ J 1916;26:537-42

6 Bales K. Lives and labours in the emergence of organised research, 18861907.J Historical Sociol 1996;9:113-38.

7 Bales K. Popular reactions to sociological research: the case of Charle Booth. Sociology 1999;33:153-68.

8 Booth C. The inhabitants of Tower Hamlets (school board division) their condition and occupations. J R Stat Soc1887;50:326-401.

9 Booth C. Life and labour of the people. First series, poverty (i) east, central and south London. London: Macmillan, 1889. (Republished 1969.)

10 Booth C. Life and labour of the people. First series, poverty (ii) streets and population classified. London: Macmillan, 1902. (Republished 1969.)

11 Booth C. Life and labour of the people in London. Final volume. Notes on social influences and conclusions. London: Macmillan, 1902.

12 Cullen M. Charles Booth's poverty survey: some new approaches. In: Smout TC, ed. The search for wealth and stability:essays in economic and social history presented to MV Flinn. London: Macmillan, 1979:115-74.

13 Davies WJD. Charles Booth and the measurement of urban social character. Area 1978;10:290-6.

14 Fried A, Elman RM. Charles Booth's London: a portrait of the poor at the turn of the century, drawn from his "Life and labour of the people in London". London: Hutchinson, 1969.

15 O'Day R, Englander D. Mr Charles Booth's inquiry: life and labour of the people in London reconsidered. London: Hambledon, 1993.

16 Pfautz HW. On the city:physical pattern and social structure: selected writing of Charles Booth. Chicago: Chicago University Press, 1967.

17 Spicker P. Charles Booth: the examination of poverty. Social Policy and Administration 1990;24:21-38.

18 Simey TS, Simey MB. Charles Booth: social scientist. London: Oxford University Press, 1960

19 Townsend P, Corrigan P, Kowarzik U. Poverty and labour in London: interim report of a centenary survey. London: Low Pay Unit, 1987. (Survey of Londoners' living standards No 1 )

20 Reeder DA. Charles Booth's descriptive map of London poverty 1889. London: London Topographical Society, 1984. (Publication No 130.)

21 Gillie A. The origin of the poverty line. Econ Hist Rev 1996;49:715-30.

22 Stevenson THC. The vital statistics of wealth and poverty. J R Stat Soc 1928;91:207-30.

23 Szreter SRS. The genesis of the registrar-general's social classification of occupations. Br J Sociol 1984:35:522-46.

24 Szreter SRS. The first scientific social structure of modern Britain 18751883. In: Bonfield L, Smith RM, Wrightson K, eds. The world we have gained: histories of population and social structure. Oxford: Blackwell, 1986:337-54.

25 Pamuk ER. Social class inequality in mortality from 1921 to 1972 in England and Wales. Popul Stud 1985;39:17-31.

26 Kunst AE, Mackenbach JP. The size of mortality differences associated with educational level in 9 industrialised countries. Am J Public Health 1994:84:932-7.

27 Davey Smith G, Hart C, Hole D, MacKinnon P, Gillis C, Watt G, et al. Education and occupational social class: which is the more importan indicator of mortality risk? J Epidemiol Community Health 1998;52:153-60.

28 Leon D, Davey Smith G. Infant mortality, stomach cancer, stroke, and coronary heart disease: ecological analysis. BMJ 2000;320:1705-6.

29 Wilkinson RG. Unhealthy societies: the afflictions of inequality. London: Routledge, 1996 